\title{
Herder and Modernity: From Lesser-Taught Languages to Lesser-Taught Cultures
}

\author{
Martin Votruba \\ University of Pittsburgh
}

\begin{abstract}
The typical North American curriculum of a lesser-taught Slavic language implicitly relies on the legacy of Johann Gottfried von Herder's interpretation that language in and of itself contains national (ethnic) culture. At the same time, enrolments are dwindling even in courses in the most commonly taught Slavic languages. Millennials' understandable focus on the practicality of the courses they take make it unlikely for the lesser-taught languages to survive the slump. On the other hand, foreign culture courses are appearing to hold their ground more successfully. Slavic departments may reconsider Herder's dictum as they try to maintain or establish programs in lesser-taught languages and cultures.
\end{abstract}

Keywords: Herder, Slavic, language, course, university.

t North American universities, the frequency with which a Slavic
language is taught does not go directly hand-in-hand with indicators
such as the number of its speakers in the country of its main use or the
number of its speakers in the world. While fewer speakers would
understandably be a strong factor to shift a language to "lesser-taught"
status, historical reasons also contribute to the allocation of status. In this
regard, Ukrainian is the most striking instance. Given the sheer number of its
speakers (Osaulenko 4), it should be taught about as often as Polish
(Witkowski et al. 17) and be well ahead of Czech. Yet, its teaching has been
affected by circumstances similar to those that have also impacted the
teaching of Slovak and Slovenian, languages with but a small fraction of the
speakers of Ukrainian. Namely, during the existence of the Soviet Union,
Czechoslovakia, and Yugoslavia, these countries promoted Russian, Czech,
and Serbo-Croatian heavily and almost exclusively as the languages, as well
as cultures, that should be studied by anyone abroad who was interested in
the respective countries. An additional albeit culturally awkward argument
was that the speakers of the countries' other languages learned the
internationally touted language at school anyway-which was actually not
even true in the case of Czechoslovakia. A European country like Belgium and
Switzerland, Czechoslovakia never had a single official language, as both
Slovak and Czech had that status. There was no inter-teaching of the two
languages; they were each the language of education and administration in 
their two respective federal states within the two-state federation. Mutual comprehension was achieved through the country's bilingual media, which alternated the two languages conscientiously, but Slovaks and Czechs never learned to speak each other's language.

Well over a quarter-century after the demise of those three multi-Slavic countries, this distorted legacy persists at an international level. In the case of Ukrainian, with over 35 million first- and second-language speakers worldwide ("Movnyi sklad..."), it has good chances of eventually shifting away from its current position, not far from the category of "lesser-taught" Slavic languages. Regardless of historical legacies, though, what might be the prospects for teaching Slavic languages that are truly spoken by few people and in countries with little political or military weight, not just in the world but also within the confines of the European continent?

The current segmentation of Slavic languages that are formally recognized as a national or regional language in at least one country is extensive (listed in descending order by the number of their self-declared or estimated speakers, excluding diasporas): Russian, Polish, Ukrainian, Czech, Serbian, Bulgarian, Croatian, Slovak, Belarusian, Slovene, Bosnian, Macedonian, Montenegrin, Kashubian, Rusyn, Upper Sorbian, and Lower Sorbian. Based on comparative numbers, the line between major and lessertaught Slavic languages can probably be drawn between the first three and the rest. Considering the definition of "lesser-taught" in the United States, Czech could probably be excluded from that category, as could the language formerly called Serbo-Croatian. The latter is still taught as a single language but under the recently expanded label Bosnian-Croatian-Serbian (usually abbreviated to $\mathrm{B} / \mathrm{C} / \mathrm{S}$ ) or, with growing frequency, Bosnian-CroatianMontenegrin-Serbian (B/C/M/S; Božović 17)—ostensibly to save space as well as to prevent puzzlement and potential nationalist accusations that each of these now formally recognized languages is not given its due respect as a separate entity. Moving on, then, to the indisputably lesser-taught Slavic languages-Bulgarian, Slovak, Belarusian, Slovene, Macedonian, Kashubian, Rusyn, Upper Sorbian, and Lower Sorbian, some of which would be more properly labelled "never taught" - there is little real chance among the West Slavic languages that Slovak, for example, with about a half the speakers of Czech, could ever reach even half the popularity of Czech. Furthermore, among the South Slavic languages, Slovenian courses would be even less likely to match the potential enrollment in what North American universities now offer as a single $\mathrm{B} / \mathrm{C} / \mathrm{M} / \mathrm{S}$ language course.

Especially in Central Europe's past, advocates of its cultures and languages would emphasize Johann Gottfried von Herder's idea that a nation's culture, "its complete wealth of views on tradition, history, religion, and principles of life reside[s] in language" (317). Without Herder 
necessarily being on modern Slavic faculty's minds in North American academia, his interpretation crossed the Atlantic and survived for almost a quarter-millennium. Indeed, language classes are commonly established as the core of lesser-taught language programs in Slavic departments. Given that language courses in Ukrainian, Polish, Czech, and B/C/M/S-justified by virtue of the numbers of their speakers or historical circumstances-do not often compete well with enrollments in some commonly taught non-Slavic languages, it is not unexpected that the lesser-taught Slavic languages will become "even-less-taught" or "not taught at all." Leaving the link between language and culture aside for the time being, a question certainly considered by most potential foreign language students is practicality. The millennials in the home territories of the lesser-taught Slavic languages now have so many years of mandatory English classes, from grade school, or middle school at the latest, through college, that North American millennials majoring in almost any field would likely be able to do business, carry out joint research, or have any other professional interactions with their peers in Central Europe and the Balkans without having to take any courses in their languages. With the exception of Belarusian, whose speakers are virtually guaranteed to be able to switch to Russian ("Rasprostranenie..."), and Macedonia's membership pending ("Relations..."), their speakers' majority areas are all militarily allied with the United States through their membership in NATO. This further reduces the likely jobs for American speakers of their languages in defence, security, and intelligence positions to a minimum. Moreover, freelance translators from and to those languages would hardly be able to support themselves, not only because of the low commissions in the US but because most written translations are outsourced by North American translation agencies and individual companies to their subsidiaries or partners in the corresponding countries and areas across the Atlantic, at lower cost (Spilka 58). That largely leaves North American students of the lesser-taught Slavic languages unemployable should they try to find a job where their foreign language would play a central role; and should they consider moving across the Atlantic to find a job, they may have an advantage with English being their native tongue, but after four or even six years of the foreign language in college, they would still find it difficult to compete with the locals with their native command added to twelve or more years of English starting at an early age.

An example of the direction of students' interests is seen in the Slovak Studies Program in the Slavic Department at the University of Pittsburgh. It has consistently offered Slovak language courses at the elementary, intermediate, and advanced level. It also offers one culture course per semester, occasionally two, taught in English. Students can obtain a Minor in Slovak Studies with fifteen credits accumulated through any of the courses. 
The university is located in Allegheny County with the historically highest percentage of people declaring Slovak ancestry of all the counties in the United States, and with several nearby counties close behind ("Table DP-2"). Such demographics might suggest some nostalgic interest in learning how one's ancestors spoke, perhaps to understand some of the phrases overheard from grandparents or lingering on in the neighbourhood or family lexicon. Yet, although there has not been a year with no enrollment in Elementary Slovak in over a quarter-century, the enrollment by millennials in the Slovak culture courses routinely beats that by a factor of four, even as great as ten. A variety of reasons are at play: each culture course has been approved by the university as meeting several curriculum requirements, they receive top ratings in anonymous evaluations, and information about them is readily accessible on the Slovak Studies Program's website (Votruba). But most of that is true about the language classes, too. Part of the reality is that when it comes to the study of a foreign language, practical considerations apply to students with ancestry in a lesser-taught culture and language, as much as to any other student. The other part of the reality is that past attempts to rely on Americans' ancestry are unlikely to work with the lesser-taught Slavic languages in the twenty-first century. Such pockets of specific ethnic groups of European Americans, established during the massive immigration before World War I, have been substantially diluted by now, four to six generations later. For instance, the 2010 US Census estimated that 300 people with Slovak ancestry in Allegheny County speak Spanish at home, and another 50 speak an Asian language ("Table B04006"). The personal histories of students who enroll in Slovak courses reflect that as well. In fact, about onethird of the students in the language classes have no Slovak ancestry, registering for a wide range of reasons. Only a fraction of the students in the culture courses are aware of any Slovak ancestry. They register because they are interested in the topic, because of course evaluations by other students, or because they need to meet a university requirement and they decided that an aspect of the given course met what they were ready to invest in fulfilling it.

This brings back Herder, on the one hand, and the goals of the North American Slavic departments, on the other, with their programs of lessertaught languages. Herder was obviously right with the truism that culture largely resides in language in the sense that a large part of what happens in a culture is conveyed by society in the language spoken among its members. But quaint idioms and grammatical structures notwithstanding, a culture and its social rules and history do not rest in what language a student can acquire in two semesters or more. A student who has taken two to four semesters of a lesser-taught Slavic language may not be easy to compare to a student who has taken two to four semesters of English-taught courses in, 
say, that culture's history, film, immigration to the US, or literature in translation, but given that the student of language will still likely need to use English for a more sophisticated discussion with a peer from the lessertaught language-cum-culture, it is likely that the one with credits for four culture courses will turn out to be more culturally aware than the one who took language courses. And considering how much faster linguistic performance fades by comparison to other knowledge, this benefit is likely to have staying power for a number of years to follow.

When North American Slavic departments address their human resource allocation mandates, they may consider the broader potential impact from offering "lesser-taught culture" courses compared to "lessertaught" language courses. With the dwindling, sometimes minuscule, or nonexistent enrollments in Bulgarian, Slovak, Belarusian, Slovene, and Macedonian language courses (not to mention Kashubian, Rusyn, Upper Sorbian, and Lower Sorbian), a minor Slavic culture could perhaps survive as an established, permanent entity in a Slavic department with several Englishtaught culture courses offered each semester and no language at all. Herder's idea that a nation's culture, "views on tradition, history, religion, and principles of life reside in language" contains the possibility that it does not actually rest in an English speaker's ephemeral contest with fast-flowing linguistic genders, cases, and aspects, but that at least some parts of a nation's culture can be successfully conveyed in language, i.e., in the English language, to North American students, with long-term results.

\section{Works Cited}

Božović, Marijeta. "From YU to EU in the Language Classroom Teaching Bosnian/Croatian/Serbian in a Time of Accession." NewsNet, News of the Association for Slavic, East European, and Eurasian Studies, vol. 53, no. 5, October 2013, pp. 16-20.

"Movnyi sklad naselennia Ukrainy." Ukrainian Census 2001, 2001.ukrcensus.gov.ua/results/general/language/. Accessed 1 Dec. 2016.

Osaulenko, Oleksandr Hryhorovych. Rozpodil naselennia naibil'sh chyslennykh natsional'nostei za stattiu ta vikom, shliubnym stanom, movnymy oznakamy ta rivnem osvity: Za danymy Vseukrains'koho perepysu naselennia 2001 roku. Derzhavnyi Komitet Statystyky Ukrainy, 2004.

"Rasprostranenie v respublike Belarus' i oblastiakh belorusskogo i russkogo iazykov: Tablitsa 5.11." Belstat, 12 Aug. 2010, http://www.belstat.gov.by/uploads/file/GU_demogr/5.11-7.pdf. Accessed 1 Dec. 2016.

"Relations with the Former Yugoslav Republic of Macedonia." NATO, 7 Apr. 2016, www.nato.int/cps/en/natohq/topics_48830.htm?selectedLocale=en\#. Accessed 1 Dec. 2016. 
Spilka, Rachel. Digital Literacy for Technical Communication: 21st-Century Theory and Practice. Routledge, 2009.

“Table B04006. People Reporting Ancestry. Universe: Total population.” United States Census Bureau.

www.pitt.edu/ votruba/sstopics/assets/ACS_10_1YR_B04006.zip. Accessed 1 Dec. 2016.

“Table DP-2: Profile of Selected Social Characteristics: 2000." United States Census Bureau. http://censtats.census.gov/data/US/01000.pdf. Accessed 1 Dec. 2016.

Von Herder, Johann Gottfried. Briefe zur Beförderung der Humanität. Erste Sammlung. Johann Friedrich Hartknoch, 1793.

Votruba, Martin. "Slovak Program." Slovak Studies Program, University of Pittsburgh. www.pitt.edu/ votruba/skprogram/skprogram.html. Accessed 1 Dec. 2016.

Witkowski, Janusz, et al. Wyniki Narodowego Spisu Powszechnego Ludności i Mieszkań 2011: Podstawowe informacje o sytuacji demograficzno-społecznej ludności Polski oraz zasobach mieszkaniowych. Główny Urząd Statystyczny, 2012. 